\title{
HIGH EFFICIENT ADAPTIVE CURRENT CHARGING OF LITHIUM ION BATTERY FOR ELECTRIC VEHICLES BY USING SIMULATION MODEL
}

\author{
Karthigayini K P M \\ Electrical and electronics engineering, \\ Rajalakshmi engineering college, India
}

\begin{abstract}
The main aim of the proposed project is to make another attempt in battery charging strategy by using optimized photovoltaic (PV) sourced charge to achieve optimal charging time in a lithium-ion battery for electric vehicles (EV). As the existing charging methods do not consider the variation of battery internal resistance, we aim to use an adaptive current charging profile based on this variation, which changes according to the state of charge (SOC). The battery pack is coupled to a PV module that also aids in charging the battery additionally and acts as a Battery Energy Storage (BES). We intend to use modified incremental conductance method to achieve Maximum Power Point Tracking (MPPT). MPPT algorithm's major principle is to extract maximum available power from PV module by making them operate at the most efficient voltage. The charge controller tracks power by measuring the voltage and current value and hence the maximum power is determined by using MPPT algorithm. When the (V/I) ratio i.e., the value of impedance $(Z)$ of the battery that is being charged is equal to the battery's internal resistance, maximum power can be obtained at this point. The simulation result shows us the values of voltage and current at different levels of charging.
\end{abstract}

Keywords---Li-ion battery, internal resistance, simulation model, Battery Energy Storage (BES)

\section{INTRODUCTION}

Owing to the environmental problems and lack of fossil fuels, the trend for adapting to green technology has been on the rise. Due to this the market for EV has been growing and opened up a large area in moving towards sustainable development. Lithium-ion battery has a higher energy density when compared to other conventional types and has proved to one of the promising energy sources for EVs. Sunlight and wind being an abundant clean source of energy, can alleviate the energy limits of batteries, while batteries can address photovoltaic and wind intermittency. The change battery's internal resistance as well the change in variable irradiance of the PV panel is considered for the maximum power extraction from the PV panel. The wind turbine also aids in optimization of the power charging of the lithium ion battery.

\section{BLOCK DIAGRAM}

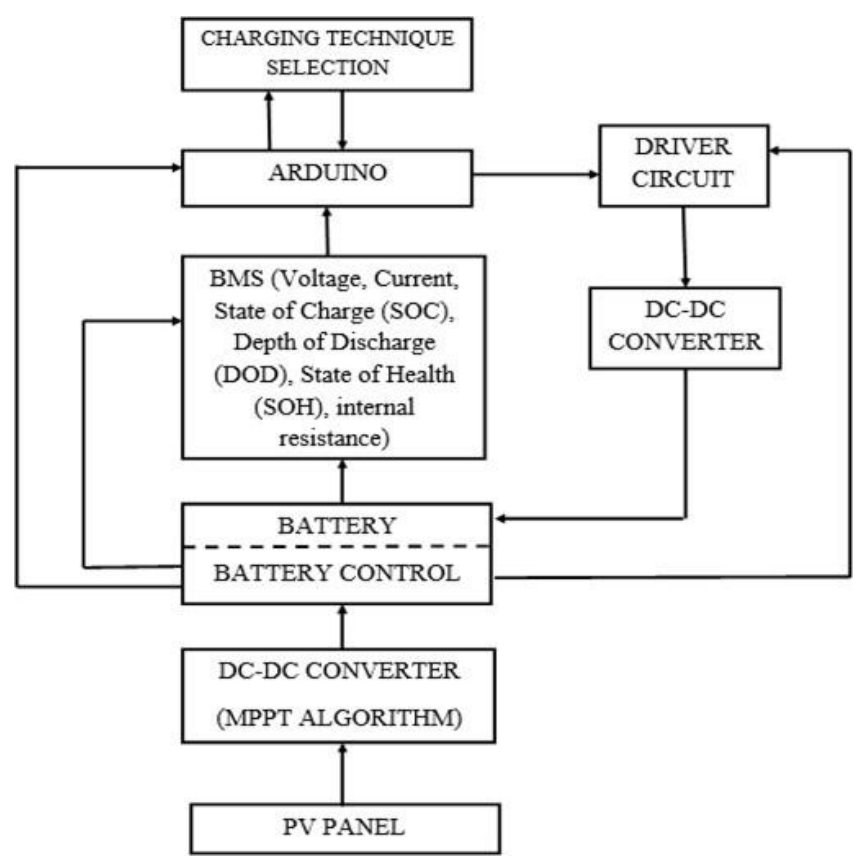

Fig .1. Block Diagram

\section{METHODOLOGY}

The battery is continuously monitored by the battery management system for the calculation of various parameters such as the State of Charge, Depth of Discharge, State of Health and internal resistance. These signals are sent to the Arduino that selects the suitable charging method for particular state of charge that is present in the battery. This transfer of charging methods is controlled by the driver circuits and intimates the charger for an efficient charging technique. The battery also serves as a supply to all the electric components that are present in the system. This 


\section{International Journal of Engineering Applied Sciences and Technology, 2020 \\ Vol. 5, Issue 6, ISSN No. 2455-2143, Pages 205-209 \\ Published Online October 2020 in IJEAST (http://www.ijeast.com)}

additional source of energy is derived from the PV and wind turbine that helps to store and maintain the charge level in the battery thereby reducing the charge time. The power optimization of the battery is obtained by engaging the suitable charging technique for the respective changes in the current and voltages of the battery as well as the PV panel.

\section{CIRCUIT DIAGRAM}

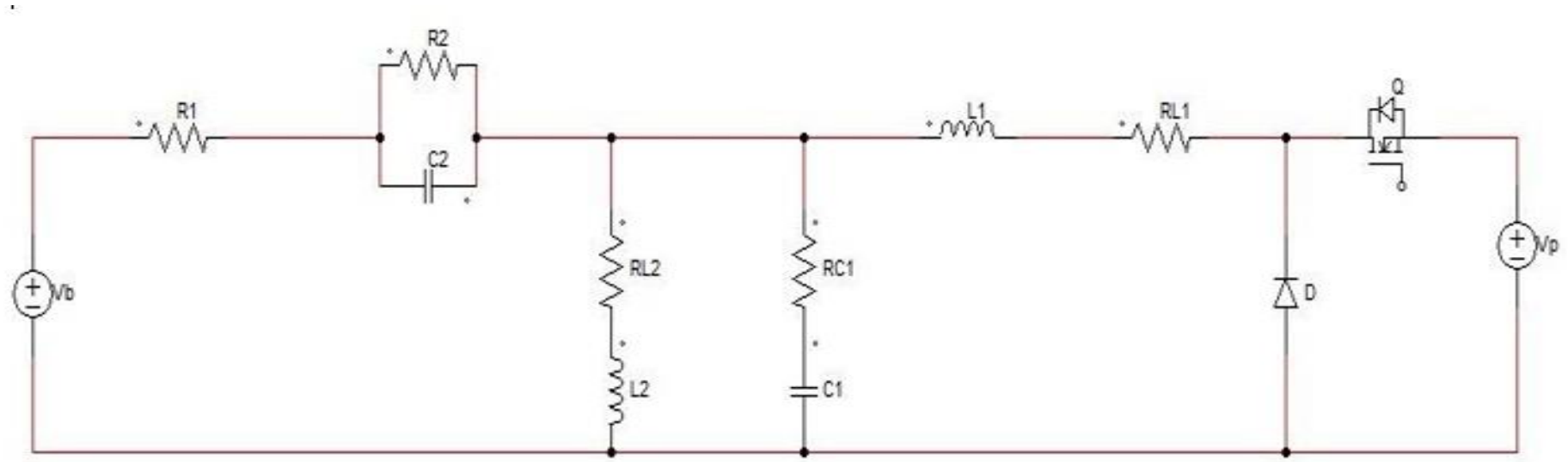

Fig .2. Circuit diagram

The above circuit diagram gives the basic idea for the design of the simulation model. The equivalent battery model along with its internal resistance $\mathrm{R} 1$ is placed on the right side and the equivalent model for the solar panel is placed on the left side. The RL load is connected in between the battery and solar panel in order get power from both the battery and solar panel. In addition to the above components a wind turbine is added in the simulation circuit in order to optimize the energy stored in the battery. The internal resistance (R1) of the battery from time to time due to the variations in the factors such as SOH, SOD and DOD. There also will be a change in the impedance value of the PV panel due to the changes in the variable irradiance. In order to get the maximum power extraction from the solar panel, the battery has to be charged in the notch point. The notch point is defined as the point where the battery's internal resistance matches with the impedance of the PV panel. The modified incremental conductance method has been used for finding the notch point by the help of a simple DC-DC (Buck) converter.

$$
\begin{aligned}
& \mathrm{Vb}=\text { Battery voltage } \\
& \mathrm{Vp}=\mathrm{PV} \text { voltage } \\
& \mathrm{RL} 2 \text { and L2 is the RL load (Motor load) } \\
& \mathrm{R} 1=\text { Internal resistance of the battery } \\
& \mathrm{Q}=\text { Switch for controlling the PV power supply } \\
& \mathrm{D}=\text { Freewheeling diode }
\end{aligned}
$$

\section{WORKING}

The above simulation model has been incorporated with four different such as load switch, battery switch, wind switch and PV panel switch for the purpose of giving real time outputs. The working of the simulation model has been classified into six different modes.

The below four modes has been implemented during the day time where there is an abundant solar energy and wind energy.

1. $\boldsymbol{P}_{p v}+\boldsymbol{P}_{b}=\boldsymbol{P}_{L}$

2. $P_{p v}=P_{L}+P_{b}$

3. $\boldsymbol{P}_{\boldsymbol{p} v}+\boldsymbol{P}_{w}+\boldsymbol{P}_{b}=P_{L}$

4. $\boldsymbol{P}_{\boldsymbol{p} v}+\boldsymbol{P}_{w}=\boldsymbol{P}_{L}+\boldsymbol{P}_{b}$

The next two modes are for the night time operations where there is not enough power can be obtained from the PV panel.

$$
\begin{array}{cl}
\text { 5. } & \boldsymbol{P}_{w}=\boldsymbol{P}_{L}+\boldsymbol{P}_{b} \\
\text { 6. } & \boldsymbol{P}_{\boldsymbol{w}}+\boldsymbol{P}_{b}=\boldsymbol{P}_{L}
\end{array}
$$

Since the simulation model is an open circuit model the changes in the internal resistance of the battery as well as the changes in the impedance of the solar panel due to the variable irradiance has been implemented by using the slider gain which has been incorporated with the values of global variables for the better function related to the real time applications. The values in the slider gain is varied intermittently during the run time and the output is obtained. The switch will be kept ON based on the different mode. 
VI. SIMULATION MODEL

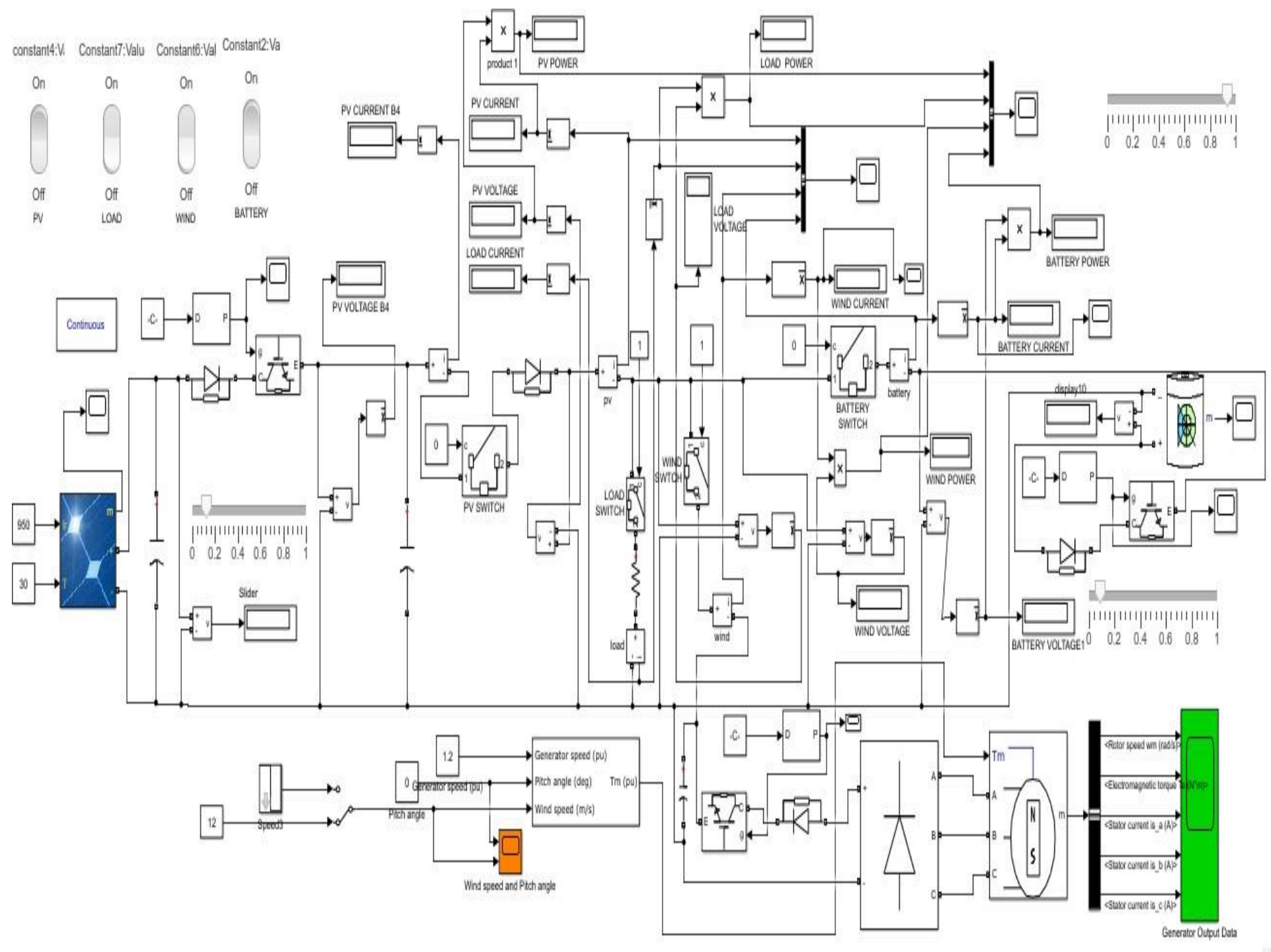


Table-1 Switching table

\begin{tabular}{|c|c|c|c|c|c|}
\hline S.NO & CASES & $\begin{array}{c}\text { SOLAR } \\
\text { SWITCH }\end{array}$ & $\begin{array}{c}\text { LOAD } \\
\text { SWITCH }\end{array}$ & $\begin{array}{c}\text { BATTERY } \\
\text { SWITCH }\end{array}$ & $\begin{array}{c}\text { WIND } \\
\text { SWITCH }\end{array}$ \\
\hline $\mathbf{1}$ & $\boldsymbol{P}_{p v}+\boldsymbol{P}_{b}=\boldsymbol{P}_{L}$ & ON & ON & SUPPLY & OFF \\
\hline $\mathbf{2}$ & $\boldsymbol{P}_{p v}=\boldsymbol{P}_{L}+\boldsymbol{P}_{b}$ & ON & ON & CHARGE & OFF \\
\hline $\mathbf{3}$ & $\begin{array}{c}\boldsymbol{P}_{p v}+\boldsymbol{P}_{w}+\boldsymbol{P}_{b}= \\
\boldsymbol{P}_{L}\end{array}$ & ON & ON & SUPPLY & ON \\
\hline $\mathbf{4}$ & $\begin{array}{c}\boldsymbol{P}_{p v}+\boldsymbol{P}_{w}=\boldsymbol{P}_{L}+ \\
\boldsymbol{P}_{b}\end{array}$ & ON & ON & CHARGE & ON \\
\hline $\mathbf{5}$ & $\boldsymbol{P}_{w}=\boldsymbol{P}_{b}+\boldsymbol{P}_{L}$ & OFF & ON & CHARGE & ON \\
\hline $\mathbf{6}$ & $\boldsymbol{P}_{w}+\boldsymbol{P}_{b}=\boldsymbol{P}_{L}$ & OFF & ON & SUPPLY & ON \\
\hline
\end{tabular}

Based on the switching table the switches are kept $\mathrm{ON}$ or OFF.

Table-2 Output values

\begin{tabular}{|c|c|c|c|c|c|c|c|c|}
\hline CASES & $\begin{array}{c}\text { PV } \\
\text { CURR } \\
\text { ENT } \\
\text { (A) }\end{array}$ & $\begin{array}{c}\text { PV } \\
\text { VOLA } \\
\text { TGE } \\
\text { (V) }\end{array}$ & $\begin{array}{c}\text { LOAD } \\
\text { CURR } \\
\text { ENT } \\
\text { (A) }\end{array}$ & $\begin{array}{c}\text { LOAD } \\
\text { VOLAT } \\
\text { GE } \\
\text { (V) }\end{array}$ & $\begin{array}{l}\text { BATTE } \\
\text { RY } \\
\text { CURRE } \\
\text { NT (A) }\end{array}$ & $\begin{array}{c}\text { BATTER } \\
\text { Y } \\
\text { VOLAY } \\
\text { GE } \\
\text { (V) }\end{array}$ & $\begin{array}{c}\text { WIND } \\
\text { CURRE } \\
\text { NT } \\
\text { (A) }\end{array}$ & $\begin{array}{c}\text { WIND } \\
\text { VOLT } \\
\text { GE } \\
\text { (V) }\end{array}$ \\
\hline $\begin{array}{c}P_{p v}+P_{b}= \\
P_{L}\end{array}$ & 3.189 & 31.92 & 3.189 & 31.92 & $\begin{array}{c}1.643 \mathrm{e}- \\
07\end{array}$ & 28.04 & 0 & 0 \\
\hline $\begin{array}{c}P_{p v}=P_{L}+ \\
P_{b}\end{array}$ & 33.167 & 31.7 & 3.1676 & 31.7 & $\begin{array}{c}-1.931 \mathrm{e}- \\
07\end{array}$ & 31.72 & 0 & 31.7 \\
\hline $\begin{array}{c}\boldsymbol{P}_{p v}+\boldsymbol{P}_{w}+ \\
\boldsymbol{P}_{b}=\boldsymbol{P}_{L}\end{array}$ & 7.498 & 29.8 & 2.977 & 29.8 & $\begin{array}{c}-5.289 \mathrm{e}- \\
07\end{array}$ & 27.96 & 4.472 & 29.8 \\
\hline $\begin{array}{c}P_{p v}+P_{w}= \\
P_{L}+P_{b}\end{array}$ & 14.87 & 10.33 & 1.032 & 10.33 & -0.0018 & 21.18 & 14.11 & 10.33 \\
\hline $\begin{array}{c}\boldsymbol{P}_{w}=\boldsymbol{P}_{b}+ \\
\boldsymbol{P}_{L}\end{array}$ & $\begin{array}{l}7.112 \mathrm{e}- \\
05\end{array}$ & 25.87 & 2.548 & 25.87 & -2.994 & 25.9 & 0.4093 & 25.87 \\
\hline $\begin{array}{c}P_{w}+P_{b}= \\
P_{L}\end{array}$ & $\begin{array}{c}6.88 \mathrm{e}- \\
05\end{array}$ & 26.08 & 2.606 & 26.08 & -2.463 & 26.11 & 0.143 & 26.08 \\
\hline
\end{tabular}

The slider gain is kept varying manually entirely during the run time for the purpose giving a real time experience to the model.

\section{CONCLUSION}

Environmental problems like air pollution and global warming are in the rise and one of the best alternatives is to opt for electric vehicles. Lithium ion battery has high charging density and is used to charge the electric vehicle. The maximum power extraction from PV is attained during charging time by considering the change in internal resistance of the battery to the variable irradiance of the PV panel. Through adaptive charging, the charging time has been improvised by charging the battery even when the load is active. Hence in the proposed method intends to charge the battery additionally through BES by PV using renewable energy so that it provides an efficient charging method by storing a good amount of charge as a backup.

\section{ACKNOWLEDGEMENT}

I would like to express my deep sense of gratitude to my project guide Dr. P SIVAKUMAR, Associate Professor, Department of Electrical and Electronics Engineering,
Rajalakshmi Engineering College for providing proper guidance to the entire project as well as constant encouragement in completing the project. I also express my thankfulness to Dr S N MURUGESAN, Principal, Rajalakshmi Engineering College, and the management for their kind support and the facilities provided to complete our work in time.

\section{REFERENCE}

[1] Jong Hoon Kim, Seong Jun Lee, Jae Moon Lee and Bo Hyung Cho (2008). A new direct internal resistance and state of charge relationship for the $\mathrm{Li}$ ion battery pulse power estimation, The $7^{\text {th }}$ international conference on Power Electronics, doi.10.1109.

[2] Jaehyung Lee, Jung-Hoon Ahn and Byoung Kuk Lee (2017). A novel Li-ion battery pack modelling considering single cell information and capacity variation, inProc. IEEE Energy Conversion Congr. And Expo., pp.5242-5247.

[3] Jung-Hoon Ahn and Byoung Kuk Lee (2019). High efficiency adaptive current charging strategy for electric vehicles considering variation of internal resistance of Li-ion battery. IEEE transactions on Power electronics, (3041-3052).

[4] Sivakumar P (2017). Maximum power extractions in a single stage PV sourced grid connected inverter during low irradiations and nonlinear loads, Renewable Energy, volume 107, 262-270.

[5] Sivakumar P (2015). Analysis and enhancement of PV efficiency with incremental conductance MPPPT technique under nonlinear load condition, Renewable Energy, 81:543-550.

[6] Jaemoon Lee, Oanyong Nam, B.H. Cho (2007). Liion battery SOC estimation method based on the reduced order extended Kalman filtering, Journal of power sources, Volume 174, Issue 1, 9-15.

[7] Saeed Khaleghi Rahimian, Sean C.Rayman and Ralph E. White (2010). Maximizing the life of Li-ion Cell by Optimization of Charging Rates, Journal of the electrochemical society, Volume 157, Issue 12, Pages A1302-A1308.

[8] Sheng Shui Zhang (2006). The effect of the charging protocol on the cycle life of a Li-ion battery, Journal of power sources, Volume 161, Issue 2, 1385-1391

[9] M. Mathew, Q.H. Kong, J. McGrory, M. Fowler (2017). Simulation of Li-ion battery replacement in a battery pack for application in electric vehicles, Journal of power sources, Volume 349, 94-104

[10] Rui Xiong, Linlin Li, Jinpeng Tian (2018). Towards a smarter battery management system: A critical review on battery state of health monitoring methods, Journal of power sources, Volume 405, 18-29.

[11] Shun-Chung Wang and Yi-Hua Liu (2015). A PSO based fuzzy controlled searching for optimal charge pattern of Li-ion Batteries, IEEE transactions on Industrial Electronics, Volume 62, Issue 5, 29832993. 
[12] Chia-Hsiang Lin, Chun-Yu Hsieh and Ke-Horng Chen (2010). A Li-ion battery charger with smooth control circuit and built-in resistance compensator for achieving stable and fast charging, IEEE transactions on circuit and systems, Volume 57, Issue2, 50-517.

[13] Sivakumar P (2018). Modified composite power control strategy for grid connected Wind-PV systems with unbalanced and nonlinear current, International Transactions on Electrical Energy Systems, DOI: 10.1002/etep.2587 